GLOBAL JOURNAL OF AGRICULTURAL SCIENCES VOL. 17, 2018: 15-22 COPYRIGHT@ BACHUDO SCIENCE CO. LTD PRINTED IN NIGERIA ISSN 1596-2903 www.globaljournalseries.com, Email: info@globaljournalseries.com

\title{
RUBBER PRODUCTION TECHNOLOGIES AND THE RELATED SOCIO-ECONOMIC ENVIRONMENTS IN AKWA IBOM STATE, NIGERIA
}

J. B. EFFIONG AND C. L. ABOH

(Received 28 September 2016; Revision Accepted 29 June 2018)

\begin{abstract}
The study assessed rubber production technologies and the related socio-economic environments in Akwa lbom State, Nigeria. The study seeks to reawaken the interests of rubber farmers in improved rubber production technologies in the study area. The specific objectives of the study were to; identify the socioeconomic characteristics of rubber farmers in the study area, identify improved rubber production technologies disseminated to farmers and to assess some socio-economic variables associated with adoption of improved rubber production technologies in the study area. Purposive and random sampling techniques were used in selecting 96 rubber farmers for the study. Primary data generated for the study were analysed using descriptive statistics such as percentages, frequencies and Multiple Regression Analysis. The result showed that Extension Officers disseminated about 13 improved rubber production technologies to farmers in the area. From the OLS regression estimates, $R^{2}$ value was 0.559 with three selected socio-economic variables being the major factors affecting adoption of improved rubber production technologies. These include; Age, Education and Contact with Extension Agents. These were significant at $1 \%$ level of probability. This calls for the re-introduction of non-formal education among farmers in the rural areas to improve their level of education and adoption of improved technologies. Government should increase the extension-farmer ratio from the present 1:1000 to 10:1000.
\end{abstract}

KEYWORDS: Rubber production, technologies, socio-economic environments, variables and Akwa lbom State.

\section{INTRODUCTION}

In many areas where agriculture is practiced, simple traditional tools are still used for production especially in rural areas. Ojo (2006), described technology as the making, modification, usage and knowledge of tools, machines techniques, craft, system, methods organization in order to solve a problem, improve pre-existing solutions, achieve a goal or perform a specific function. According to Basu (2009), technology can be viewed as the practical application of discoveries made by scientists for the production of goods and services necessary for improvement of man's life. Thus technology entails ways of applying scientific and other organized knowledge to practical task with a view to improving welfare, productivity and standard of living (Effiong and Asikong, 2013). Technologies embrace a range of definitions, a vast spectrum of tools, software and hardware component, social organization and productive machinery (Campbell, 2000). Spore (2007) in a broad sense conceived technology as the translation of scientific laws into machines, tools, mechanic devices, instruments, innovation, procedures and techniques to accomplish tangible ends, attain specific needs or manipulate the environment for practical purpose in agriculture. This represents new models of organizing production as well as the development of techniques for regulating and controlling behaviours, delivery services and improving advancement in agriculture. It is therefore, instrumental in upgrading farmers' welfare, increasing the efficiency of small, medium and large scale farmers (Effiong and Asikong, 2013).

\section{Improved Rubber Production Technologies adopted by farmers:}

Agwu (2004), identified improved rubber production technologies in Nigeria, they include the use of improved rubber planting materials (RRTN 500, NIG 801 and NIG 805), snail farming in rubber plantations, use of Ethel to stimulate rubber yield, use of agrochemicals, recommended disease and pest control measures, among others. Okunola (2005) in a research on factors affecting adoption of rubber based technologies among small-holder farmers outlined five improved rubber production technologies, they include; the use of NIG 800 rubber series, intercropping, use of integrated livestock/rubber production techniques and NIG 500 series. Integration of NIG 800 with be keeping, use of recommended fertilizer, clearing of plantation before commencement of tapping, clearing of latex cup and use

\section{J. B. Effiong, Department of Agricultural Extension and Rural Sociology, Faculty of Agriculture, Forestry and Wildlife,} Resources Management, University of Calabar, Calabar, Cross River State, Nigeria.

C. L. Aboh, Department of Agricultural Extension and Rural Sociology, Faculty of Agriculture, Forestry and Wildlife, Resources Management, University of Calabar, Calabar, Cross River State, Nigeria. 
technologies listed in Giroh, Ephraim, Fannp, Igbinosun and Ogwuche (2007); Ndifon, Echua and Nkang (2007), while evaluating the utilization level of improved rubber technologies suggested use of budded stumps, intercropping, recommended and land spacing of 450 plants/hectares, application of NPK 15:15:15 and urea. Other are use of trained tappers, clearing of latex cup before tapping, cleaning of coagulating pan before tapping, use of raised platform and cemented surfaces, clearing of plantation before commencement of tapping, use of agrochemcials, use of ammonia as preservative, use of force-trace and improved clones like NIG 500 series, RRTN 600, GTI, PB5/63 and RRIN 62B. Schroth, Moraes and Demota (2004), listed their improved rubber production technology as thus; the use of grafting technology or technique, improved nursery management, disease management technologies, appropriate tapping method and clone identification. Giroh, Abubakar, Balogun, Wuranti and Ogbebor (2006) comprehensively gave a list of improved rubber production practices to include the use of recommended and disease resistant clones, the use of young green and brown budded technique, marcotting propagation, use of sulphur to control leaf disease, use of $\mathrm{NaCl} /$ rock phosphate in place of $\mathrm{KCl}$ and TSP fertilizers, use of fungicide and pesticides, mini livestock integration, food crop integration, periodical tapping, hypodermic tapping, upward tapping, use of mini creeper, use of rubber seeds for seed oil production, latex determination using microwaves/creeper machine and the processing of concentrated latex using creaming method.

\section{Factors affecting adoption of Improved Rubber Production Technologies:}

Several studies have pointed to the fact that different socio-economic environments play prominent role in the adoption of new technologies by peasant fanners in agricultural sector (AKSMANR, 2011 and Mgbeje, 2005).

Inadequate contact by farmer with extension agents on one part is one of the factors affecting farmers' adoption of recommended technologies. Agwu (2004) and Ekong (2010) found that contact with extension officers was necessary to motivate rubber farmers in Akwa lbom State to adopt recommended practices. Basu (2009), stated that social participation by the farmers had a significant relationship with the adoption of recommended practices. Also the age of a farmer was important in the adoption of improved practices in rubber farming. Begno, Abubakar and Akpaja (2000), made a similar discovery that, farmers who were young, had high aspiration and relatively large acreage of land were willing to be innovators. Rogers and Shoemaker (2001) in a famous adopter categorization, noted that individuals are willing to adopt innovation in any social system. This happened when such individuals have control of substantial financial resource to absorb the possible loss on account of unprofitable innovation and have ability to apply complex technical knowledge. However, it is widely acknowledged that most farmers or individuals would not adopt a new practice if they find revenue.

According to Effiong, Effiong and Udo (2015), source of finance is also a factor that affects adoption of improved technologies this is because, if the farmers have access to financial source, it would be easy to obtain the required inputs. Other factors are lack of credit facilities, low labour supply and non-availability of improved varieties (Effiong, Ndifon and Onyeye, 2012).

Effiong, Effiong and Udo (2015) stated that small holders have a lion share of abandonment and alarming rate of decrease in hectares of land planted with rubber trees in Nigeria. The private rubber companies embarked on community development projects aimed at improving welfare of rural people of the host communities. For instance, Ndifon et al., (2007), in a study on the corporate social responsibility functions of Rubber Industries and the felt needs for community development of its host communities in Cross River State confirmed that Rubber Industries provided employment opportunities, rural roads, electricity and water supply to its host communities. It is true that rubber production is contributing about $40.0 \%$ to the present day Nigerian economy (RRIN, 2004). The establishment of the Rubber Research Institute of Nigeria (RRIN) was aimed at overcoming the problems facing rubber production technologies to Nigeria (Udom, 2006). The Institute has led to the development of improved technologies for rubber production. Efforts have been made to disseminate these technologies to farmers by RRIN agents and similar agencies in Nigeria (Eskekhede, Ugwa and Aigbekaen, 2006).

Several adoption awareness have been made over the years by Rubber Research Institutes and other organizations to enlighten farmers on the benefits of adoption of improved rubber production technologies including employment generation and income. It is not expected of farmers to hesitate the adoption (Effiong, Ndifon and Odunuga, 2012). Yet farmers to some extent have exhibited a cautious attitude towards adoption of improved rubber production technologies. This study therefore seeks to reawake the interests of rubber farmers in adoption of improved production technologies.

\section{Objectives of the study}

The general objective of the study was to analyse rubber production technologies and the related socio-economic environments in Akwa Ibom State, Nigeria.

The specific objectives of the study were to;

i. identify the socio-economic characteristics of respondents in the study area.

ii. identify improved rubber production technologies disseminated to farmers in the study area.

iii. analyse some socio-economic variables affecting adoption of improved rubber production technologies by the study area.

\section{METHODOLOGY}


Akwa Ibom State of Nigeria was the study area. The state lies between longitudes $4^{\circ} 31^{\prime}$ and $8^{\circ} 25^{\prime}$ East of the equator and Latitudes $4^{\circ} 33^{\prime}$ and $5^{\circ} 35^{\prime}$ North of the Greenwich Meridian. The state is located in the forest belt of Nigeria. The state has 31 Local Government Areas with 6 Agricultural Zones namely; Uyo, Eket, Etinan, Oron, Abak and Ikot Ekpene. The soil found in the area is generally fertile and is sandy loam in nature. The area is suitable for cultivation of many food and cash crops such as Maize, Cassava, Oil Palm, Rubber, Cocoa among others.

\section{Method of data collection}

Six Local Government Areas were covered in the study namely; Onna, Itu, Uyo, Ikot Ekpene, Etinan and Nsit Atai, list of farmers were obtained from the respective block extension agents. A purposive sampling technique was used to select six (6) Local Government Areas from the high and low rubber producing areas of the state. Sixteen (16) rubber farmers were randomly selected from each of the Local Government Areas giving a total of 96 farmers used for the study.

\section{Analytical technique}

Objective (i) and (ii) was analysed using descriptive statistics such as percentages and frequency table while objective three was realized using the multiple regression estimates.

\section{Model specification:}

The four functional forms of regression models via linear, semi-log, exponential and Cob-Douglas was tried. The best fit was chosen as the lead equation based on its conformity with econometric and statistical criteria such as F-ratio, magnitude of $\mathrm{R}^{2}$, number of significant variables and a priori expectations.

The four functional forms are as shown below:

\section{i. Linear Function:}

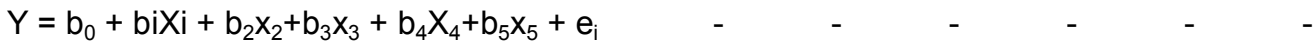

ii. Semi log Function:

$Y=L_{n} b_{0}+b_{1} L_{n} X_{1}+b_{2} L_{n} X_{2}+b_{3} L_{n} X_{3}+b_{4} L_{n} x_{4}+b_{5} L_{n} X_{5}+e_{i} \quad-\quad-\quad-\quad-\quad$ -

iii. Cobb-Douglas Function:

$L_{n} Y=L_{n} b_{0}+b_{1} L_{n} X_{1}+b_{2} L_{n} x_{2}+b_{3} L_{n} x_{3}+b_{4} L_{n} x_{4}+b_{5} L_{n} x_{5}+e_{i}-\quad-\quad$ - $\quad$ -

iv. Exponential Function:

$L_{n} Y=b_{0}+b i X_{2}+b_{2} x_{2}+b_{3} x_{3}+b_{4} x_{4}+b_{5} x_{5}+e_{i} \quad-\quad-\quad-\quad-\quad-\quad-$

$\begin{array}{lll}\text { Where } & & \\ \mathrm{Y} & = & \text { Adoption level } \mathrm{X} \\ \mathrm{X}_{1} & = & \text { Age of Rubber Farmers (in years) } \\ \mathrm{X}_{2} & = & \text { Farming Experience (in years) } \\ \mathrm{X}_{3} & = & \text { Educational Status (years of schooling) } \\ \mathrm{X}_{4} & = & \text { Extension Contact (No. of Visits) } \\ \mathrm{e}_{\mathrm{i}} & = & \text { Error term. }\end{array}$


RESULTS AND DISCUSSION

Table 1: Socio-economic characteristics of respondents

\begin{tabular}{|c|c|c|}
\hline Variables & Number of respondents & Percentage \\
\hline \multicolumn{3}{|l|}{ Age range (Years) } \\
\hline $21-40$ & 22 & 22.91 \\
\hline $41-60$ & 46 & 47.92 \\
\hline 61 and above & 28 & 29.17 \\
\hline Total & 96 & 100.00 \\
\hline \multicolumn{3}{|l|}{ Sex } \\
\hline Female & 6 & 6.25 \\
\hline Male & 90 & 93.73 \\
\hline Total & 96 & 100.00 \\
\hline \multicolumn{3}{|l|}{ Level of formal education } \\
\hline No schooling & 18 & 18.75 \\
\hline Primary education & 44 & 45.83 \\
\hline Secondary education & 22 & 22.92 \\
\hline Tertiary education & 12 & 12.50 \\
\hline Total & 96 & 100.00 \\
\hline \multicolumn{3}{|l|}{ Farming experience in years } \\
\hline $1-20$ & 34 & 35.41 \\
\hline $21-40$ & 28 & 29.18 \\
\hline 41 and above & 34 & 35.41 \\
\hline Total & 96 & 100.00 \\
\hline \multicolumn{3}{|l|}{ Frequency of extension contact } \\
\hline Non & 30 & 31.25 \\
\hline Quarterly & 24 & 25.00 \\
\hline Monthly & 42 & 43.75 \\
\hline Total & 96 & 100.00 \\
\hline \multicolumn{3}{|l|}{ Marital status } \\
\hline Single & 12 & 12.50 \\
\hline Married & 74 & 77.08 \\
\hline Widowed & 4 & 4.17 \\
\hline Divorced & 6 & 6.25 \\
\hline Total & 96 & 100.00 \\
\hline \multicolumn{3}{|l|}{ Farm size of farmers } \\
\hline 0.50 & 46 & 47.92 \\
\hline $1.00-5.00$ & 44 & 45.83 \\
\hline 6.00 and above & 6 & 6.25 \\
\hline Total & 96 & 100.00 \\
\hline \multicolumn{3}{|l|}{ Level of awareness and adoption } \\
\hline Yet to be aware & 4 & 4.16 \\
\hline Aware but not yet practicing & 12 & 12.50 \\
\hline Aware and are using it & 70 & 72.92 \\
\hline Aware used and have discontinued & 10 & 10.42 \\
\hline Total & 96 & 100.00 \\
\hline \multicolumn{3}{|l|}{ Monthly income (A) } \\
\hline$<10,001$ & 10 & 10.41 \\
\hline $10,001-20,000$ & 21 & 21.88 \\
\hline $20,000-30,000$ & 42 & 43.75 \\
\hline $30,000-40,000$ & 5 & 5.21 \\
\hline$>40,000$ & 18 & 18.75 \\
\hline Total & 96 & 100.00 \\
\hline
\end{tabular}

Source: Field Survey Data, 2015.

Socio-economic characteristics of respondents: Table 1, showed the socio-economic characteristics of the respondents. The results in Table 1, showed that majority $(47.92 \%)$ of the respondents were in the age brackets of $41-60$ years. Majority $(93.75 \%)$ of the respondents were males, while a small proportion $(6.25 \%)$ were females. $(45.83 \%)$ had primary level education. Also, majority $(35.41 \%)$ of the respondents had farming experience ranging from 41 years and above.
Similarly, majority $(77.08 \%)$ of the respondents were married, a good proportion $(47.92 \%)$ had farm size of 0.50 hectare of land, while $(43.75 \%)$ had income ranging from $\mathrm{N} 20,000.00-\mathrm{N} 30,000.00$ only.

The findings revealed that most of the farmers were in their middle and productive age and as such a bright prospect for the rubber production industry (Effiong et al, 2015). Interest of citizens (males and females) in tree crop production business (rubber, oil palm, cocoa amongst others) is of particular importance in terms of 
employment which is the main focus of the present government.

The respondents had good income from rubber production. They were fairly educated and could adopt improved varieties of rubber seedlings and other rubber production technologies. According to Effiong and Effiong (2015), major socio-economic environments associated with adoption of improved rubber, oil palm and cocoa production are; age of the farmers, farming experience, educational status and contact with extension organizations among very many others.

Table 2: Improved Rubber production Technologies disseminated to farmers by extension officers

\begin{tabular}{|c|c|c|c|}
\hline $\mathbf{S} / \mathbf{N}$ & Improved technology & $\begin{array}{l}\text { Frequency } \\
(n=96)\end{array}$ & $\begin{array}{l}\text { Percentage } \\
(\%)\end{array}$ \\
\hline \multirow[t]{5}{*}{1} & Planting materials & & \\
\hline & a. Planting of RRIN 500 Malaysia & 95 & 99.00 \\
\hline & b. RRIN 600 & 93 & 97.00 \\
\hline & c. RRIN 801 & 93 & 97.00 \\
\hline & d. RRIN 625 & 91 & 94.00 \\
\hline \multirow[t]{4}{*}{2} & Use of fertilizer & & \\
\hline & a. Urea & 85 & 88.00 \\
\hline & b. Fertilizer sp 36 & 82 & 85.00 \\
\hline & c. Fertilizer kcl & 80 & 83.00 \\
\hline \multirow[t]{3}{*}{3} & Tapping & & \\
\hline & a. Improved tapping technique & 79 & 82.00 \\
\hline & b. Recommended tapping time & 50 & 52.00 \\
\hline 4 & Using polybags for nursery operation & 42 & 90.00 \\
\hline 5 & Ploughing or harrowing of land before cultivation & 87 & 43.00 \\
\hline 6 & Intercrop with other crops & 57 & 59.00 \\
\hline 7 & Recommended pest/disease control & 56 & 58.00 \\
\hline
\end{tabular}

Distribution of Farmers according to the disseminated Improved Rubber Production Technologies by Extension Agents:

The distribution of the respondents according to the improved rubber production technologies disseminated is shown in Table 2. The table showed that rubber farmers respond to improved rubber production technologies extended to them in varying degrees. The responses showed that farmers are familiar with some of these technologies. Example; planting of RRIN 500 Malaysian type (99.00\%). RRIN 600 (97.00\%), RRIN $801(97.00 \%)$, use of urea fertilizer (88.00\%), SP 36 $(85.00 \%), \mathrm{KCl}$ fertilizer $(83.00 \%)$, improved tapping technique $(82.00 \%)$, recommended tapping $(52.00 \%)$, use of polybags for nursery operation $(90.00 \%)$, intercropping with other crops $(59.00 \%)$ and recommended pest/disease control (58.00\%). But they are yet to accept ploughing or harrowing of land before cultivation (43.00\%). This could be because of the labour intensive nature of the technology. Effiong et al, (2015) in their study on the socio-economic determinants of production of Pro-vitamin A cassava production in Etim Ekpo, opined that ploughing and harrowing are labour intensive, it therefore hinder increase production where there are no tractor for the operations.

Also, this study is in tandem with the findings of Williams and Williams (2004); Effiong, Ijioma and Effiong (2016) who suggested use of the clones improved for high productivity, by introducing clone rubber instead of the traditional seedlings with low yield potentials. Considerable research has been conducted on natural rubber in areas of crop improvement and other production innovations and technologies in Akwa Ibom state in particular and Nigeria in general. 
Table 3: OLS Regression estimates of selected socio-economic variables affecting adoption of Improved rubber production Technologies by farmers in Akwa Ibom State

\begin{tabular}{lllll}
\hline Variables & $\begin{array}{l}\text { *Linear } \\
\text { Function }\end{array}$ & Double log & Semi-log & Exponential \\
\hline Age & $0.98^{* * *}$ & $3.299^{* * *}$ & $0.45^{* * *}$ & $8.45^{* * *}$ \\
& $(5.147)$ & $(2.486)$ & $(5.130)$ & $(3.35)$ \\
Farming Experience & $-077^{* * *}$ & $-0.318^{* *}$ & $034^{* * *}$ & $-1.267^{* *}$ \\
& $(-4.148)$ & $(-2.73)$ & $(-4.65)$ & $(-2.187)$ \\
Educational Status & $0.54^{\star * *}$ & 0.194 & $093^{\star * *}$ & 0.408 \\
& $(2.354)$ & $(1.195)$ & $(24.31)$ & $(1.173)$ \\
Contact with & $0.323^{\star * *}$ & $-0.383^{* * *}$ & $0.147^{* * *}$ & $-1.373^{* * *}$ \\
Extension Agent & $(3 . B 9)$ & $(-3.68)$ & $(3.122)$ & $(-3.140)$ \\
$\mathrm{R}^{2}$ & 0.559 & 0.301 & 0.250 & 0.307 \\
$\mathrm{R}$ & 0.553 & 0.295 & 0.235 & 0.302 \\
$\mathrm{~F}$ statistic & $41.475^{* * *}$ & $4.488^{* * *}$ & $5.321^{* * *}$ & $6.232^{* * *}$ \\
\hline
\end{tabular}

Source: Field Survey Data, 2015

*** Significant at $1 \%$

** Significant at $5 \%$

Variables in parenthesis are t-values

${ }^{*}$ Lead equation

The result in Table 3 showed the OLS multiple regression estimates of selected socio-economic variables affecting adoption of improved rubber production technologies by farmers in the study area. Four functional forms were fitted to the data and linear function was chosen as the lead equation based on a high $R^{2}$ value, number of significant variables and agreement with apriori expectation. The $R^{2}$ value of 0.559 indicated that $55.9 \%$ of the variations in the adoption of improved rubber production technologies were accounted for by the included variables.

The coefficient of age $(0.98)$ was positively signed and highly significant at $1.00 \%$ level of probability. Increase in age brings about increase in the level of adoption of improved rubber production technologies (Ndifon, 2006). This is in agreement with the priori expectation. Age of the farmer can have effect on technology adoption. The effect came from accumulated knowledge and experience of farming systems and techniques obtained over the years (ljioma, Effiong, Ogbonna and Achu, 2012).

The coefficient for education (0.154) was positively signed and significant at $1.00 \%$ level of probability. This means that increase in level of education leads to increase in level of adoption of improved rubber production technologies, this is in consonance with the apriori expectation. This findings agree with the study conducted on the functions of youth organization in Nigeria by Effiong et al, (2012) that higher level of education results in high level participation, adoption and community development activities.

The coefficient of extension contact (0.323) was positively signed and significant at $1.00 \%$ level of probability. This implies that increase in adoption of improved rubber production technologies is as a result of frequent extension contact. Extension enhances adoption of improved technologies among farmers (Effiong et al, 2012). The coefficient of farm experience $(-0.77)$ was negatively related to adoption. This means that experienced farmers find it difficult to try new ideas. This is in agreement with Effiong, Ndifon, and Odunga (2012) that experienced farmers find it difficult to try new technologies for fear of uncertainties.

\section{CONCLUSION}

This study indicated that improved rubber production technologies such as the planting of RRIN 500 Malaysian species, RRIN 600, RRIN 801, RRTN 625, fertilizers, urea, SP36 and $\mathrm{KCl}$, tapping type, use of polybags for nursery operations and the ploughing or harrowing of land before cultivation were disseminated to rubber farmers by extension officers in the study area. Also some selected socio-economic variables such as age, level of education and contacts with extension officers were responsible for adoption of improved rubber technologies among farmers. Rubber production enterprise should be integrated into the agricultural reform policy programmes of government. This will help in the fight against unemployment and poverty in Akwa Ibom State in particular and Nigeria in general.

\section{REFERENCES}

Agwu, A. E., 2004. Factors influencing adoption of improved cowpea production technologies in Nigeria. Journal of International Agricultural and Extension Education, 2(1), pp. 81-85.

Akwa Ibom State Ministry of Agriculture and Natural Resources (AKSMANR) (2011). Annual Report, Akwa Ibom State Government Press, pp.8-10. 
Basu, A. N., 2009. The Relationship of farmers characteristics to the adoption of recommended farm practices in four villages of the Western State of Nigeria: Bulletin of Rural Economic Society, 4(1), pp. 112-116.

Begno, E. R., Abubakar, M. and Akpaja, E. O., 2002. Farmers perception of the Mistletoe problem on Rubber Trees in Southern Nigeria. Journal of Agriculture for Farm \& Fisheries, 3 and 4:5-8.

Campbell, M. J., 2000. New Technology in Rural Development, the Social Impact. Routledge Press, London, pp. 5-6.

Ekong, E. E., 2010. An Introduction to Rural Sociology. Third Edition, Dove Educational Publishers, Uyo, Nigeria.

Effiong, J. B., Ijioma, J. C. and Effiong, M. O., 2016. Endogenous determinants of adoption of improved rubber production technologies among farmers in Akwa Ibom State, Nigeria. Asian Journal of Agricultural Extension, Economics and Sociology, 8(4): 2-7.

Effiong, J. B., Effiong, G. B. and Udo, U. A., 2015. Socio-economic determinants of production of pro-vitamin A cassava varieties by farmers in Etim Ekpo Local Government Area, Akwa Ibom State, Nigeria. Global Journal of Pure and Applied Sciences. Vol. 21, (2015) pp 106-109.

Effiong, J. B. and Effiong, G. B., 2015. Adoption of improved rubber production technologies by farmers in Akwa Ibom State, Nigeria. Global Journal of Agricultural Science. Vol.14 (2015).

Effiong, J. B. and Asikong, A. B., 2013. Mid-term Assessment of the activities of Fadama III Development Projects in Cross River State. Global Journal of Agricultural Science, 12(1):3134.

Effiong, J. B., Ndifon, H. M. and Onyeye, C. C., 2012. Functions of Youth Organizations in Agricultural and Community Development. Nigeria Journal of Contemporary development Studies (NJCDDS). Centre for Research and Manpower Development (CREMD) Owerri. Vol. 5. No. 3, pp 42-43.

Effiong, J. B., Ndifon, H. M. and Odunuga, O. A., 2012. Determinants of Social change among rural farmers in Nigeria. International Journal of Agricultural and Development Economics (IJADE) Vol. 2, No. 2, pp 95-100.

Eskekhede, T. U., Ugwa, I. K. and Aigbekaen, E. O., 2006. "Suitability and Economic viability of intercropping in Rubber in Acid Sandy soils of Southern Nigeria". Indian Journal of Natural Rubber Resource, 9(1): 36-39.
Giroh, D. Y., Abubakar, M., Balogun, F. E., Wuranti, V. and Ogbebor, O. J., 2006. "Adoption of Rubber Quality Innovations among Small Holder Rubber Farmers in two farm settlements of Delta State", Nigeria Journal of Sustainable Development in Agriculture and environment, 2: 74-79.

Giroh, D. Y., Ephraim, I. J., Fannap, D., Igbinosun, F. O. and Ogwuche, P., 2007. "A qualitative analysis of adoption of natural rubber production technologies among farmers in Southern Nigeria". Journal of sustainable Crop and Agricultural Resources, pp.11-19.

Ijioma, J. C, Effiong, J. B., Ogbonna, M. O. and Achu, B. A., 2012. Analysis of factors affecting Women's participation in Women-In-Agriculture (WIA) programme of Abia State Agricultural Development Programme in Umuahia Zone, African Journal of Agricultural Research and Development.. Devon Sceince. Vol. 5 No4, pp. 125-126.

Mgbeje, B. I. A., 2005. "The Nigeria Small Holder in the African Rubber Programme". Paper presented at Workshop for Rubber Small-holders organized by the Federal Ministry of Commerce, held at Motel Plaza, Benin City, Edo State, $14^{\text {th }}$ Feb., pp. 19-21.

Ndifon, H. M., Echua, R. O. and Nkang, M. N., 2007. Corporate social responsibility and community development. A case study of PAMOL (Nig.) Rubber Estate, Cross River State, Nigeria. The Social Sciences Journal. 3(2); Pp. 14-20.

Ndifon, H. M., 2006. Theory and practice of Agricultural Extension Management. Munson Global Resource, Calabar, Cross River State, pp 5557.

Ojo, S. O., 2006. "Productivity and technical efficiency: A comparative analysis of oil palm farms in Ondo State, Nigeria". Journal of Agriculture and Fisheries. 1:40-43.

Okunola, J. O., 2005. "Factors associated with the adoption of Food Crops Production Technologies by small scale farmers in Niger Republic". Ogun Journal of Agricultural Sciences, 40: 20-32.

Rogers, E. M. and Shoemaker, F. F., 2001. "Communication of Innovations". 2 ${ }^{\text {n }}$ Free Press, New York.

Rubber Research Institute of Nigeria (RRIN)., 2004. "Rubber Production in Nigeria": A Monograph published by Rubber Research Institute of Nigeria. pp.13-16.

Schroth, G, Moraes, U. R. F. and Da Mota, M. S. S., 2004. "Increasing the profitability of traditionally planted rubber agro-forest at Tapojo's River, Brazilian 
Amazon". Journal of Agric. Ecosystem and Environment, 102: 319-330.

Spore Magazine., 2007. "Natural Rubber Springs Back". Bimonthly Bulletin of the Centre for Agricultural Research (CTA), pp. 11-15.

Udom, E. R., 2006. "Problems of Agricultural Development in Nigeria, our Collective Amnesia". A paper presented at the Annual Conference of the Rectors of the Colleges of Agriculture held at the Michael Okpara College of Agriculture, Umuagwo, Imo State, September 2006, pp.71-72.
Williams, C. E. and Williams, S. K. T., 2004. Agricultural user population and their information needs. A case study of Badeku pilot rural development project in Nigeria. Proceedings of CAB's Scientific Conference. Arusha, Tanzania, pp.156-160. 